\title{
Menstimulasi Praktik Gereja Rumah di tengah Pandemi Covid-19
}

Fransiskus Irwan Widjaja ${ }^{1}$, Candra Gunawan Marisi²,

T. Mangiring Tua Togatorop ${ }^{3}$, Handreas Hartono ${ }^{4}$

1, 2, 3Sekolah Tinggi Teologi REAL, Batam, Kepulauan Riau, Indonesia

${ }^{4}$ Sekolah Tinggi Teologi Pelita Bangsa, Jakarta, Indonesia

1irwanwidjaja.fiw@sttrealbatam.ac.id, 2candragun@sttrealbatam.ac.id,

3togatoroptimo@gmail.com,4handreas@sttpb.ac.id

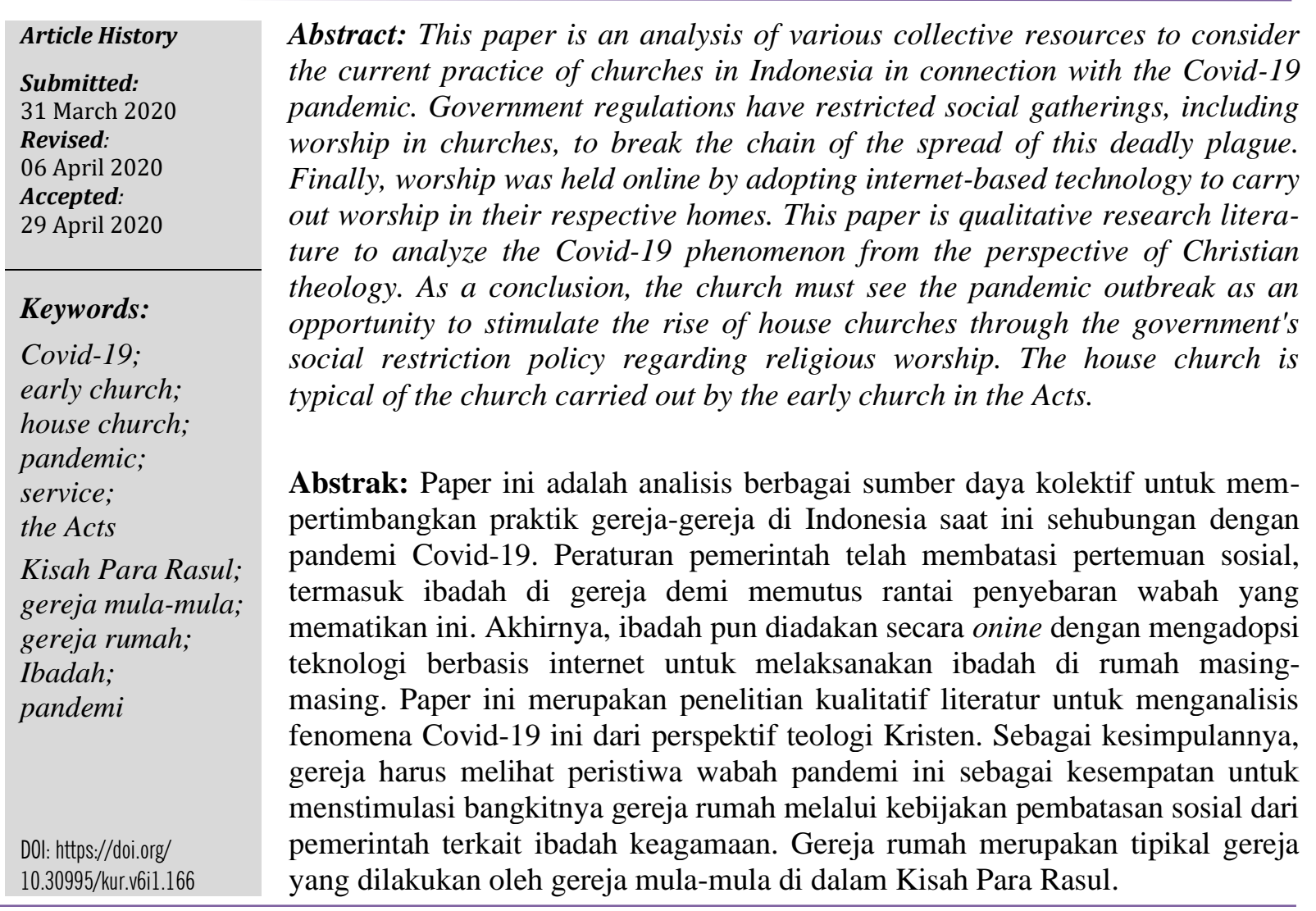

\section{Pendahuluan}

Virus Corona atau yang lebih dikenal dengan sebutan Covid-19 telah menjadi pandemic bagi dunia sebagaimana yang dikeluarkan Badan Kesehatan Dunia (WHO), pada tanggal 11 Maret 2020 oleh Dr. Tedros Adhanom Ghebreyesus, WHO's Director-General. ${ }^{1}$ Data resmi dari John Hopkin university di bulan Maret minggu ke tiga tahun 2020, menunjukkan negaranegara yang terindikasi penyakit Virus Corona sudah mendekati 189 negara, orang yang terpapar per 25 Maret 2020, 416.916 kasus, dengan jumlah kematian sebanyak 18.565 jiwa. $^{2}$

\footnotetext{
${ }^{1}$ Eka Yudah Saputra, "WHO Tetapkan COVID-19 Sebagai Pandemi, Apa Maksudnya?," Tempo, accessed March 20, 2020, https://dunia.tempo.co/read/1318511/who-tetapkan-covid-19-sebagai-pandemi-apamaksudnya/full\&view=ok.

${ }^{2}$ https://hub.jhu.edu/novel-coronavirus-information/, diakses tanggal20 maret 2020
} 
Sementara itu, di Indonesia per tanggal 25 Maret 2020 sumber pemerintah menunjukkan angka 790 kasus dan 58 orang yang meninggal. ${ }^{3}$ Penyakit ini membuat kegaduhan di seluruh dunia, sehingga sebagai cara untuk memutus mata rantai penuluran secara luas banyak negara melakukan lockdown, atau melakukan penutupan akses keluar dan masuk daerah atau wilayah tertentu. Sementara di Indonesia pemerintah mencoba menerapkan social distancing hingga Pembatasan Sosial Berskala Besar (PSBB). Akibatnya, banyak sektor publik yang harus dibatasi hingga penutupan. Sekolah-sekolah terpaksa harus non aktif, tidak ada kegiatan belajar di kelas, melainkan melakukan belajar dari rumah. Tempat-tempat keramaian pun demikian mengalami pembatasan, seperti tempat wisata atau pusat perbelanjaan. Orang-orang diarahkan untuk bekerja dari rumah (WFH). Semua dilakukan untuk memutus penyebaran wabah yang mematikan tersebut.

Bukan saja pada sektor sosial, pendidikan, ekonomi, namun pembatasan juga dilakukan pada sektor keagamaan, yakni dilarangnya melakukan kegiatan keagamaan di rumah-rumah ibadah. Pemerintah meminta agar semua bentuk peribadatan dilakukan di rumah atau menerapkan teknologi yang dapat mendukung. Berbagai reaksi pun muncul menanggapi kebijakan dan strategi pemerintah tersebut; ada yang dapat menerima dan mendukung, namun tidak sedikit yang menolak dan memrotesnya. Alih-alih menenangkan umat dan memberikan edukasi, beberapa pemimpin agama, khususnya di lingkungan umat Kristen, malah mengeluarkan pandangan yang kontra produktif. Dan tidak ayal kegaduhan pun sempat terjadi, antara yang berpandangan negatif dan mencoba menyikapi pesan pemerintah secara positif. Beberapa pemimpin umat menganggap tindakan beribadah dari rumah dengan mengikuti ibadah live streaming adalah tindakan kurang iman, takut menghadapi tantangan. Ungkapan yang disampaikan lewat khotbah dan diteruskan secara masif kembali mengundang pro dan kontra di kalangan gereja.

Menyikapi fenomena yang sedang terjadi memang tidak dapat memuaskan semua orang, atau katakanlah gereja, terlebih lagi gereja di Indonesia memiliki denominasi yang begitu banyak. Masing-masing denominasi mewakili pola piker teologis dan dogmatis yang khas, sehingga cara pandang terhadap sebuah situasi akan berbeda sekalipun menggunakan kitab yang sama dan satu dalam berpendapat. Yang menarik adalah, ada banyak hal dalam Alkitab yang boleh dikatakan mirip dengan keadaan yang sedang terjadi sekarang. Atau ada teks-teks yang dianggap sebagai nubuatan tentang situasi yang sedang terjadi di masa ini. Pandanganpandangan yang muncul di dunia maya atau internet kebanyakan merupakan posting-an yang cenderung bersifat liar, karena tidak menggunakan pendekatan teologis dan ditulis dalam sebuah kajian yang mewakili sikap akademis. Akibatnya, penelitian tentang fenomena Covid19 yang dibingkai dalam pandangan teologis ini boleh dikatakan sangat minim, dibandingkan dengan tulisan para teolog atau pendeta di akun media sosial mereka, atau melalui tayangan youtube. Artikel ini mencoba membuat sebuah kajian teologis tentang pandemi yang sedang terjadi ini secara ilmiah dengan pendekatan metodologis terhadap fakta dan simulasi hermeneutis.

${ }^{3}$ http://covid-monitoring.kemkes.go.id/, diakses tanggal 21 Maret 2020 
Pembahasan dalam artikel ini lebih kepada menentukan sikap teologis gereja dalam melihat sebuah tantangan yang sedang dihadapi. Tantangan yang dimaksud adalah, pertama, keberadaan wabah virus Corona itu sendiri, dan, yang kedua, sikap terhadap pembatasan beribadah di gereja. Gereja harus dapat melihat sebuah situasi yang terjadi menjadi sebuah peluang untuk menerapkan trik atau strategi dalam melayani Tuhan. Wabah Covid-19 ini diartikulasikan dalam banyak bentuk pemahaman; ada yang menganggapnya sebagai sebuah bentuk penyakit Sampar modern, atau nubuatan tentang akhir zaman yang memasuki babak penghujung. Semua hal tersebut sah-sah saja karena, sekali lagi, cara menafsirkan teks Alkitab oleh masing-masing denominasi tentulah berebeda-beda.

Sebuah artikel yang menanyakan sikap gereja terhadap Covid-19 ini adalah hasil penelitian yang dilakukan oleh Jabin B. Deguma dan rekan, di mana mereka membingkai Covid-19 dalam sebuah persoalan social gereja. ${ }^{4}$ Dengan menggunakan pendekatan teologi pembebasan ala Gustavo Gutierez, paper ini melakukan sebuah refleksi teologis apa yang seharusnya gereja lakukan di tengah pandemi ini. Pandangan yang dibangun sangat realistis, jika itu diperhadapkan dengan situasi gereja di Indonesia saat ini, hal ini dapat menjadi sebuah refleksi iman yang Kristen yang baik. Tidak sedikit juga tugas-tugas perkuliahan yang mencoba menstimulasi perspektif mahasiswa untuk menanggapi secara teologis fenomena Covid-19 ini, seperti yang dilakukan oleh Institut Agama Kristen Negeri (IAKN) Toraja. Tugas-tugas yang diunggah di repositori preprint OSF memberikan pandangan yang beragam tentang Covid-19 ini, walau dengan pendekatan biblikal.

Thalia Yusuf menggunakan pendekatan Mazmur 91:1-16, seperti yang digunakan kebanyakan orang Kristen juga, untuk menyikapi Covid-19 ini. ${ }^{5}$ Nats ini sering digunakan umat Tuhan dalam membangun iman demi menghadapi fenomena Covid-19 ini. Pada dasarnya, gereja menyikapi wabah Covid-19 ini dalam dua hal yang umum; pencobaan dan ujian, fakta tentang semakin dekatnya akhir zaman atau kesempatan untuk melihat pertolongan Tuhan. Namun demikian, ada satu hal yang menjadi titik temu gereja dalam situasi ini, yakni mereka berpengharapan agar keadaan ini cepat berlalu. Persoalannya, jika memang gereja melihat bahwa setiap keadaan yang diijinkan terjadi dan gereja mengalami, senantiasa memiliki kebaikan, maka sisi misteri kebaikan inilah yang harus ditelisik lebih dalam. Apakah gereja sedang dilatih, untuk menghadapi situasi misteri yang masih terbungkus dan tersimpan dalam ruang waktu ilahi. Karena, jika masa Covid-19 berlalu, apakah bencana, penderitaan, atau situasi buruk lainnya pun sudah berhenti, atau lebih berat? Semua masih dalam sebuah ruang misteri ilahi.

Minimnya penelitian tentang keadaan ini mungkin saja disebabkan oleh pemikiran bahwa Covid-19 hanyalah salah satu jenis dari penderitaan yang diijinkan Tuhan terjadi atas manusia. Intinya, adalah penderitaan atau situasi buruk itu dapat mengambil berbagai bentuk

\footnotetext{
${ }^{4}$ Jabin J. Deguma et al., "Where Is the Church in the Time of COVID-19 Pandemic: Preferring the Poor via G. Gutierrez' 'Liberation' and the Catholic Church's Social Teaching in the Philippine Setting," Journal of Social and Political Sciences 3, no. 2 (2020): 363-374, https://www.asianinstituteofresearch.org/JSParchives/Where-is-the-Church-in-the-Time-of-COVID-19Pandemic\%3A-Preferring-the-Poor-via-G.-Gutierrez'-"Liberation"-and-the-Catholic-Church's-Social-Teachingin-the-Philippine-Setting.

${ }^{5}$ Thalia Yusuf, Gaya Hidup Orang Percaya Berlandaskan Mazmur 91 : 1-16 Dalam Menyikapi Masalah Virus Corona (Covid-19) Masa Kini (Toraja, 2020), https://osf.io/kc6ea/.
} 
dan rupa, bisa penyakit, bencana alam, dan hal lain yang tak terduga. Namun demikian tidak sedikit yang mencoba menghubungkan peristiwa ini dengan nubuatan Alkitab. Sebut saja nats dalam Hagai 2:7-9, "Sebab beginilah firman TUHAN semesta alam: Sedikit waktu lagi maka Aku akan menggoncangkan langit dan bumi, laut dan darat; Aku akan menggoncangkan segala bangsa, sehingga..." Penekanan pada kata "menggoncang" bisa diartikulasikan dengan keadaan sekarang dengan wabah pandemic Covid-19 ini, bahwa seluruh dunia terguncang. Ayat-ayat Alkitab yang berbicara tentang keadaan seperti ini memang dapat ditemukan dalam beberapa tempat lain. Namun, sekali lagi, fokus penelitian ini lebih menyikapinya saja, termasuk sikap atas kebijakan ibadah yang tidak lagi dilakukan di gereja.

Pemerintah, baik secara langsung maupun melalui Bimas Kristen Protestan Kementrian Agama R.I., menyerukan agar ibadah tidak lagi daiadakan di gereja, melainkan secara online dengan teknologi streaming. ${ }^{6}$ Hari-hari ini tidak sedikit gereja yang mulai terdampak secara ekonomi oleh wabah Covid-19 yang mengharuskan orang beribadah di rumah, setidaknya ada implikasi pada menurunya pemasukan finansial gereja. Saling kritik pun tak terhindari terjadi di media sosial, demi mempertahankan realita kehidupan yang membutuhkan biaya yang tidak sedikit. Ada yang merasa kurang etis jika pemimpin gereja mencoba melakukan strategi mengedarkan kantong kolekte, atau mengedarkan nomor rekening pribadi. Namun, semua hal dan tindakan yang dilakukan oleh masing-masing gereja dan pemimpinnya tidaklah dapat digene-ralisir, karena setiap -masing gereja memiliki konteks dan daya tahan finansial yang berbeda. Persoalan finansial gereja harus dilihat secara teknis, karena terkait dengan kebijakan masing-masing, selain fakta bahwa gereja adalah institusi sosial yang memiliki kebutuhan selayaknya masayarakat secara umum.

Yang perlu dicermati di sini adalah, mulai bermunculan pelayanan-pelayanan yang terkait dengan digitalisasi. Setiap pelayanan harus dapat mengaktualisasikan diri dengan eranya ${ }^{7}$, termsuk dengan era digital sekarang ini. Tidak dapat dibayangkan jika keadaan seperti ini menerpa gereja di masa tahun 1980-an di mana internet masih begitu asing sekali. Bukankah peristiwa ini dapat dijadikan momentum, karena persoalan social distancing dapat diatasi dengan virtual meeting ala teknologi digital melalaui aplikasi video conference. Itu satu hal yang harus dilihat sebagai sisi baik, bahwa gereja menembus batas-batas fisik, hadir dalam ruang yang lebih luas dan dapat dinikmati oleh siapa saja. Momentum lain adalah munculnya ibadah-ibadah rumah, yang meng-ingatkan kembali pada masa para rasul, di mana mereka membangun gereja rumah.

\section{Metode Penelitian}

Ini merupakan penelitian dengan pendekatan kualitatif pada persoalan faktual pandemi Covid19 sebagai pemicu munculnya gereja rumah di masa sekarang ini. Penelitian ini juga merupakan penelitian fenomenologis, yang memperhatikan fenomena pandemi sebagai sebuah variabel yang membentuk korelasi terhadap munculnya gereja rumah sebagai variabel

\footnotetext{
6“Hindari Kontak, Kemenag Harap Gereja Gelar Ibadah Secara Online,” accessed March 29, 2020, https://bimaskristen.kemenag.go.id/news-126-hindari-kontak-kemenag-harap-gereja-gelar-ibadah-secaraonline.html.

${ }^{7}$ Harls Evan R. Siahaan, “Aktualisasi Pelayanan Karunia Di Era Digital,” EPIGRAPHE: Jurnal Teologi dan Pelayanan Kristiani 1, no. 1 (2017): 23-38, www.stttorsina.ac.id/jurnal/index.php/epigraphe.
} 
lainnya. Metode deskriptif digunakan untuk memberikan gambaran yang jelas pada persoalan pandemi Covid-19 dan gereja rumah yang diaktualisasikan pada masa pandemi sekarang ini. Penggunaan literatur terkait pandemi Covid-19 dan pandangan Alkitab tentang strategi gereja rumah.

\section{Pandemi Covid-19}

Penjelasan tentang Covid-19 tidaklah diuraikan secara detail di sini, karena ini merupakan hal aktual yang sedang terjadi dan dialami oleh masyarakat Indonesia, khususnya umat Kristen. Penelitian ini adalah penelitian pada ranah teologis yang ingin memberikan sikap pada kasus pandemi ini secara refleksi iman Kristen, sehingga isu Covid-19 tidak perlu dibahas dalam kerangka medis, kecuali ekses sosial yang diakibatkan olehnya. Yang pasti, masyarakat gereja pada konteks ini telah memiliki pemahaman yang sederhana dan representatif tentang Covid19 sebagai wabah penyakit yang memiliki daya tular yang cepat dan dapat mengakibatkan kematian.

Ada pendapat yang mencoba menghubungkan wabah ini merupakan penyakit sampar versi modern. Istilah sampar tertulis 50 kali dalam Alkitab; 46 kali dalam Perjanjian lama dan 4 kali dalam perjanjian Baru. Penyakit ini dikategorikan sebagai "Pestilence" yang berarti penyakit menular yang mematikan. ${ }^{8}$ Sampar pertama kali disebut dalam kitab Keluaran 5:3, di mana Harun dan Musa meminta ijin kepada Firaun untuk pergi beribadah. Akibat ketegaran hati Firaun, Tuhan melepaskan Sampar bukan hanya untuk ternak tetapi juga merambah kepada manusia (Kel. 9:15). Selanjutnya kata sampar sudah tidak asing lagi di telinga orang Israel. Bahkan dalam suatu peristiwa, Tuhan meminta Daud untuk memilih hukuman ketika Daud menjadi tinggi hati, salah satu hukuman mendatangkan sampar selama 3 hari (2 Sam. 24:13), dan Alkitab mencatat hampir tujuh puluh ribu rakyat tewas karena penyakit sampar.

Sampar dalam bahasa Ibrani דָרבר (deber) yang berarti: pestilence; plague; murrain, cattle disease; cattle-plague. ${ }^{9}$ Septuaginta menterjemahkan kata tersebut dengan kata $\theta \dot{\alpha} \nu \alpha \tau$ (thanatos) yang dapat diartikan death, of natural death. Penggunaan thanatos dalam Septuaginta kemung-kinan tidak adanya padanan kata Sampar dalam Bahasa Yunani. Dalam

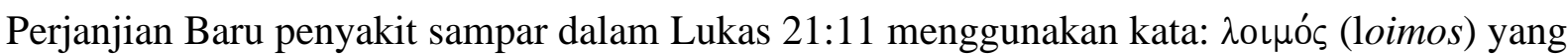
berarti: pestilence; a pestilent fellow, pest, plague; origin: of uncertain affinity. ${ }^{10}$ Sampar dapat diterjemahkan sebagai suatu penyakit yang menular yang dijinkan Tuhan untuk menghukum orang Israel maupun orang Mesir di dalam zaman Perjanjian Lama dengan kematian yang begitu cepat.

Sampar Moderen tercatat dalam sejarah permulaan pertengahan tahun 1300, dimana kapal kapal dari Laut Hitam merapat di pelabuhan Sisilia, yang menimbulkan kematian mecapai 20 juta orang di Eropa, sampar ini di kenal dengan nama Black Death. ${ }^{11}$ Sejarah juga mencatat pada awal abad ke-20, dalam zaman Dinasti Manchuria ada epidemi wabah pneumonia

\footnotetext{
${ }^{8}$ https://kbbi.web.id/sampar disadur tanggal 21 Maret 2020

${ }^{9}$ BibleWorks7 Keluaran 5:3

${ }^{10}$ Ibid., Lukas 21:11

${ }^{11}$ https://www.history.com/topics/middle-ages/black-death, 21 Maret 2020
} 
primer. $^{12}$ Salah satu catatan sejarah epidemi semacam sampar dan mendapat perhatian terbatas, terjadi pada tahun 1904 di Johannesburg, Afrika Selatan, berdekatan dengan ladang emas Witwatersrand, yang sering di sebut Bubonic plague. ${ }^{13}$ Setelah itu, muncul juga virus virus yang lain seperti Ebola, Flu babi, flu burung, Flu Mers, flu Sars dan lain sebagainya. Tetapi semua flu yang ada tidak secepat dan seganas flu Covid-19 yang merata di banyak negara. Covid-19 dapat dianggap sebagai penyakit sampar modern bukan hanya menimbulkan kematian, tetapi telah di ikuti krisis keuangan dan kelaparan.

Yang menarik dari pandemi ini adalah dampak sosial atau konsekuensi yang dimunculkan dalam rangka memutus mata rantai penyebarannya yang masif. Dampak sosial yang paling terasa adalah dibatasinya kerrumunan masa dalam jumlah yang besar dan jarak yang sangat dekat hingga bersentuhan. Pembatasan sosial yang lebih dikenal dengan istilah social distancing atau physical distancing ini mengakibatkan ibadah di gereja pun harus dialihkan dalam bentuk yang ramah terhadap social distancing. Artinya, Covid-19 dalam konteks ini dianggap sebagai pemicu munculnya trend ibadah dengan live streaming yang bisa diakses oleh setiap keluarga dari rumah masing-masing.

\section{Gereja Rumah}

Konsep gereja rumah bukanlah hal yang baru dalam dunia kekristenan, karena prototipe-nya dapat ditemui dalam pola ibadah jemaat mula-mula. Tidak ada definisi yang pakem untuk istilah gereja rumah ini, sehingga pemahaman tersebut dapat dibangun dari fenomena gereja rumah ala para rasul di Kisah Para Rasul. Walaupun Kisah Para Rasul sendiri tidak memberikan definisi secara gamblang tentang konsep ini, setidaknya pengertian itu dapat dipahami dalam beberapa pola yang dilakukan oleh jemaat mula-mula dalam Kisah Para Rasul. Djeffry Hidajat menyebutkan bahwa gereja dalam Perjanjian Baru adalah gereja rumah; karena rumah merupakan unit sosial, ekonomi dan religius. ${ }^{14}$ Itu sebabnya pada masa para rasul kegiatan ibadah dan pengajaran rohani mengenai iman Kristen biasa diadakan di rumah-rumah.

Dalam Alkitab Perjanjian Baru kata "rumah" banyak digunakan, menghasilkan 274 ayat, baik dalam pengertian harfiah maupun metafora. Sebutan untuk "rumah" dalam Bahasa Yunani adalah oikos atau oikia. Menurut Collin Brown arti yang paling banyak muncul dalam Perjanjian Baru untuk oikia dan oikos adalah dalam arti dasar yaitu rumah, bangunan atau tempat tinggal; oikos 46 kali dan oikia 71 kali. ${ }^{15}$ Banyaknya penggunaan oikos dan oikia menunjukkan bahwa penulisan teks-teks Perjanjian Baru mempunyai latar belakang para pembaca jemaat gereja rumah. ${ }^{16}$ Kata oikos lebih dimengerti sebagai rumah dan tempat

\footnotetext{
${ }^{12} \mathrm{H}$ Nishiura, "Epidemiology of a Primary Pneumonic Plague in Kantoshu, Manchuria, from 1910 to 1911: Statistical Analysis of Individual Records Collected by the Japanese Empire," International Journal Epidemiol 35, no. 1 (2006): 1059-1065.

${ }^{13}$ CM Evans, Egan JR, and Hall I, "Pneumonic Plague in Johannesburg, South Africa, 1904.," Emerging Infectious Diseases 24, no. 1 (2018): 95-102.

${ }^{14}$ Djeffry Hidajat, "Gereja Di Rumah: Kontekstualisasi Fungsi-Fungsi Rumah Dalam Masa Perjanjian Baru Untuk Pekabaran Injil,” Veritas : Jurnal Teologi dan Pelayanan 17, no. 2 (December 2018): 107-117.

${ }^{15}$ Collin Brown, ed., New International Dictionary of New Testament Theology. Vol. 2 (Grand Rapids: Zondervan Publishing House, 1986), 247.

${ }^{16}$ Hidajat, "Gereja Di Rumah: Kontekstualisasi Fungsi-Fungsi Rumah Dalam Masa Perjanjian Baru Untuk Pekabaran Injil."
} 
tinggal tetapi merujuk juga pada sebuah tempat ibadah. ${ }^{17}$ Kata oikia dalam Perjanjian Baru dapat berarti rumah, keluarga atau rumah tangga. ${ }^{18}$ Itu sebabnya jika melihat ke dalam Kisah Para Rasul, maka para rasul melayani dan melakukan ibadah dari rumah ke rumah, seperti salah satunya di rumah Kornelius (Kis. 10).

Paulus dalam pelayanannya selalu memulai dari rumah. Rumah menjadi pusat awal pekabaran Injil di kota-kota yang Paulus layani dan juga tempat membina orang-orang percaya di kota-kota itu. Filipi, Paulus tinggal di rumah Lidia (Kis. 16:15-16), rumah Yason di Tesalonika (Kis. 17:7), rumah Akwila di Korintus (Kis. 18:1), ruang atas di Troas (Kis. 20:8, 11), rumah Filipus di Kaisarea (21:8). Paulus juga melayani jemaat di rumah-rumah tertentu: jemaat di rumah Priskila dan Akwila (Rm. 16:3-5); rumah Aristobulus (Rm. 16:10), rumah Narkisus (Rm. 16:11), Gayus yang memberi tumpangan (Rm. 16:23), jemaat di rumah Nimfa (Kol. 4:15), Paulus pernah tinggal di rumah Karpus di Troas (2Tim. 4:13). Hasil buah pelayanan dari pemberitaan kabar baik di rumah, juga di tuntaskan di rumah. Hal ini menjelaskan mengapa dalam Perjanjian Baru terdapat banyak baptisan serumah, misalnya Kornelius (Kis.10:2; Lidia di Filipi (Kis. 16:15) dan kepala penjara (Kis. 16:33), Keluarga Stefanas di Korintus (1Kor. 1:16; 16:5).

E.A. Judge menjelaskan bahwa pertobatan serumah bukan hanya alamiah dan diperlukan untuk memantapkan agama baru dalam lingkungan yang belum dikenal, tetapi rumah adalah merupakan fondasi paling masuk akal untuk pertemuan Kristen. ${ }^{19}$ Fungsi religius rumah juga tampak ketika orang Kristen mula-mula memilih rumah sebagai tempat beribadah. Menurut Gehring fungsi gereja rumah dijelaskan dalam dua aspek, yaitu aspek eklesiologis dan aspek misiologis. ${ }^{20}$ Struktur gereja rumah bagi Gehring penting untuk melakukan pekerjaan misi dan pekabaran Injil. ${ }^{21}$

\section{Rumah Misi}

Gereja Mula-mula adalah gereja rumah merupakan bangunan gereja yang umum pada masa dua abad pertama. ${ }^{22}$ Penggunaan rumah bagi ibadah Kristen mula-mula juga menguntungkan untuk penerimaan sosial masyarakat di luar Kristen, para tetangga maupun pihak berwenang setempat. ${ }^{23}$ Dengan demikian orang Kristen mula mula merasa aman untuk bertemu sebagai kelompok sosial dan terhindar dari perhatian umum. Gereja menggunakan struktur rumah sebagai media karena sudah ada dalam masyarakat sebelumnya sehingga tidak perlu membentuk lagi yang baru tetapi menggunakan bentuk yang sudah ada. Hal ini merupakan kontekstualisasi yang memudahkan untuk melakukan penyebaran iman Kristen kepada orangorang lain.

\footnotetext{
${ }^{17} \mathrm{G}$ Kittel and G Friedrich, Theological Dictionary of the New Testament, ed. W. Tr. Geoffrey and Bromiley., 5th ed. (Grand Rapids: Eerdmans, 1985).

${ }^{18}$ Ibid, 130

${ }^{19}$ E.A. Judge, "The Social Pattern of Christian Groups in the First Century," The Journal of Romans Studies 50, no. 1-2 (1960): 283.

${ }^{20} \mathrm{R}$ Gehring, "House Church and Mission: The Importance of Household Structures in Early Christianity.," The Journal of Theological Studies 58, no. 2 (2007): 666-671.

${ }^{21}$ Ellis EE., Pauline Theology: Ministry and Society (Grand Rapids: Eerdmans, 1989).

${ }^{22}$ Hidajat, "Gereja Di Rumah: Kontekstualisasi Fungsi-Fungsi Rumah Dalam Masa Perjanjian Baru Untuk Pekabaran Injil."

${ }^{23}$ Ellis EE., Pauline Theology: Ministry and Society, 144.
} 
Rumah menjadi basis pekerjaan misi serta menjadi pusat organisasi jemaat lokal dan perte-muan ibadah. Paulus mengintegrasikan struktur rumah dalam masyarakat dengan strategi misi. ${ }^{24}$ Bagi Paulus gereja rumah tetap menjadi sel dasar gereja lokal, ia jelas ingin gereja rumah itu membentuk satu tubuh dengan satu sama lain di dalam gereja di seluruh kota. Paulus membayangkan semacam federasi/rayonisasi dari beberapa gereja rumah membentuk gereja lokal. Dengan demikian, gereja lokal model Paulus ada di dua tingkat, keduanya terhubung dengan rumah tangga. Pertemuan rumah tangga dari satu keluarga dan orang-orang yang terkait dengan keluarga itu, dan pertemuan tingkat kota di rumah pribadi tetapi terdiri dari beberapa keluarga. ${ }^{25}$ Branick menjelaskan dengan sangat baik bahwa tidak semua rumah tangga dipertobatkan dalam setiap kasus - dan itulah sebabnya Paulus harus membahas masalah pasangan yang tidak percaya; di mana waktu itu Onesimus, budak yang melarikan diri, bukanlah seorang Kristen ketika ia melarikan diri dari Filemon. Menurut Barnick (1989:25) ${ }^{26}$ Model gereja Rumah Paulus tidak terjadi di semua kota. Paulus tidak pernah menyebut Roma sebagai gereja. Branick percaya bahwa ada banyak gereja rumah di Antioch yang tidak memiliki pertemuan seluruh kota.

Paulus menggunakan struktur sosial yang sudah ada yang dikenali oleh orang Kristen maupun orang bukan Kristen. Paulus menggunakan secara khusus rumah tangga untuk mengorganisasi gerakan Kristen mula-mula Dan kesuksesan misi Kristen mula-mula dan kehidupan gereja sangat terkait dengan rumah. ${ }^{27}$ Konteks penyebaran agama saat itu yang paling dikenali adalah konteks rumah dan rumah tangga. Hal ini juga yang dilakukan oleh Yudaisme dengan sinagogenya, agama mistis dengan sekte-sektenya dan bahkan sekolah filsafat-sekolah filsafat tertentu. Paulus telah menggunakan struktur rumah tangga yang ada dalam masyarakat untuk menyebarkan kekristenan. ${ }^{28}$ Model Paulus ini diikuti oleh para misionaris dan pekabar Injil pada masa berikutnya. Hal ini sejalan dengan kontekstualisasi struktur rumah yang memungkinkan pekabaran Injil bagi jaringan sosial di sekitar rumah tangga Kristen. Ibadah seperti ini terus bertahan sampai pada masa penganiaayaan. Melihat keadaan dan situasi dunia secara umum dan Indonesia secara khusus, di mana pandemi Covid-19 yang dianggap sebagai sampar modern sedang merajalela, serta dilarangnya beribadah dalam jumlah besar, gereja rumah dapat menjadi solusi. Bangkitnya gereja rumah tentu juga harus diiringi dengan kegairahan penyampaian kabar baik melaksanakan amanat Agung. ${ }^{29}$

\section{Pembahasan}

Tujuan dari hasil pengumpulan data, analisa dan diskusi, untuk mempresentasikan penemuan, kesimpulan, pendapat akan fenomena pandemic Covid-19 dikaitkan dengan kegerakkan

\footnotetext{
${ }^{24} \mathrm{~V}$. Branick, The House Church in the Writings of Paul (Wilmington, Delaware: Michael Glazier, 1989), $18-20$.

${ }^{25}$ Ibid.

${ }^{26}$ Ibid.

${ }^{27}$ E.J. Schnabel, Early Christian Mission: Paul and the Early Church (Downers Grove: IVP Books, 2004), 1301.

${ }^{28}$ John Corrie, ed., Dictionary of Mission Theology: Evangelical Foundations (Nottingham: IVP, 2007), 70.

${ }^{29}$ Susanto Dwiraharjo, "Kajian Eksegetikal Amanat Agung Menurut Matius 28 : 18-20," Jurnal Teologi Gracia Deo 1, no. 2 (2019): 56-73, http://sttbaptisjkt.ac.id/e-journal/index.php/graciadeo.
} 
gereja zaman ini, tentu juga dengan saran dan usulan untuk meneliti lebih lanjut. Hasil dan diskusi dari data untuk menjawab pertanyaan pada bagian pendahuluan, di mana dengan kejadian yang luar biasa ini, diperkirakan gereja akan kembali ke sistem gereja rumah, di mana persekutuan atau ibadah-ibadah rumah akan seperti di Kisah Para Rasul, seperti yang dilakukan jemaat mula-mula (Kis. 2:41-47). Dengan bangkitnya gereja-gereja rumah, diharapkan Amanat Agung bisa dimaksimalkan sebelum kedatangan Tuhan yang kedua.

\section{Perubahan Cara Beribadah}

Melihat situasi keadaan dunia secara umum dan Indonesia secara khusus, dengan keadaan semua dilarang berkumpul dalam jumlah besar dan harus kembali di rumah untuk mengurangi atau memberhentikan penyebaran Covid-19, hampir semua sektor kehidupan merasakan dampaknya. Salah satunya adalah dibatasinya ibadah di gereja. Sebagian besar gereja, baik di Indonesia maupun luar negeri sudah tidak lagi mengadakan pertemuan bersama di gedung gereja, mereka melakukan ibadah di rumah secara online. Awalnya, ada banyak sikap pendeta yang tidak sejalan dengan anjuran pemerintah tersebut, namun seiring berjalannya waktu hampir setiap minggunya ibadah dilakukan secara live streaming.

Fenomena sampar modern ini telah menstimulasi gereja untuk melakukan strategi dalam beribadah, tidak terbatas pada pola konvensional, yakni bertemu di rumah ibadah. Ketika bait Allah yang didirikan Salomo dihancurkan oleh tentara Babel, hal tersebut mengubah cara pandang selama berabad-abad Kerajaan Yehuda, yang menjadikan bait Allah di Yerusalem sebagai kebanggaan dan pusat ibadah. Hancurnya bait Allah, bangsa Yehuda dipaksa untuk memikirkan ulang esensi ibadah mereka. Suku Yehuda menyimpulkan dalam ibadah bukanlah persembahan, tetapi ketaatan (1Sam. 15:22). Pembuangan ke Babel membuat paradigma yang berbeda dalam ibadah umat Tuhan: fokus pada ritual (persembahan kurban) bergeser pada ketaatan (pengajaran firman). ${ }^{30}$ Ibadah bersama dalam skala besar sekarang menjadi ibadah dalam skala yang lebih kecil. Gereja modern, khususnya gereja-gereja yang telah menerapkan komsel secara baik tidak terlalu kesulitan menerapkan sistem ini, ibadah di rumah-rumah.

Peristiwa Covid-19 ini harus dilihat secara berimbang, dalam artian tidak sekadar pada wabah penyakit menular dan mematikan yang harus memaksakan pembatasan sosial dan berdampak pada gereja. Karena sejatinya, Covid-19 ini hanya sebuah bentuk lain dari wabah yang lain yang pernah ada dan akan ada lagi, seperti halnya sampar. Wabah seperti ini pernah ada sebelumnya, dan umat Tuhan diajarkan untuk menyatakan sikap terkait pola ibadahnya. Dan ketika wabah yang hampir serupa ini muncul lagi dan mungkin dengan intensitas yang lebih besar, maka lagi-lagi gereja saat ini harus menyatakan sikap, juga terkait pola ibadahnya. Artinya, yang perlu ditandaskan dalam kasus ini adalah sebuah sikap untuk tetap menyatakan ibadah kepada Allah dalam beragam bentuk yang disesuaikan dengan zamannya.

Esensi gereja rumah adalah gereja atau ibadah yang fokus pada persekutuan keluarga sebagai pilar gereja. Anggaplah ini sebuah kesempatan untuk melatih atau merevitalisasi kekuatan keluar-ga sebagai benih gereja yang perlu dikuatkan secara fondasional. Tidak harus

\footnotetext{
${ }^{30}$ M. S. Panjaitan, F. Lumingkewas, "Ibadah Jemaat Kristen Kontemporer Abad 21 Dan Tinjauan KritisLiturgis," FIDEI: Jurnal Teologi Sistematika dan Praktika 2, no. 1 (2019): 162-185.
} 
mencontoh bentuk yang kaku dari gereja mula-mula, namun esensi yang dibangun oleh mereka, yakni bertekun dalam pertemuan ibadah $^{31}$, karena inilah sejatinya yang menjadi karakteristik jemaat Pentaskostal awal. ${ }^{32}$ Pentakosta tidak berbicara tentang aliran atau denominasi, melainkan dinamika perkembangan sekaligus pertumbuhan gereja mula-mula yang terjalin dari rumah ke rumah, keluarga ke keluarga.

Gereja rumah tidak juga harus dimaknai dalam sebuah situasi yang konvensional, keterasingan seperti halnya para murid di abad pertama yang bersembunyi dari kejaran pemerintah Romawi, atau dalam ketakutan. Intinya adalah membangun sebuah mezbah ibadah dalam konteks zaman dan situasi yang sedang dialami. Era digitalisasi saat ini jangan dipaksakan untuk melakukan secara ideal pola yang sama dengan jemaat mula-mula, kecuali spirit atau dinamika yang dibangun oleh para rasul saat itu. Spirit-nya adalah tentang misi, menjadi saksi dan memenangkan jiwa bagi Kristus. Namun teknik dan mekanismenya tidak dapat dipaksakan pada model dulu, namun mengadopsi media yang dapat diterapkan dalam masa kini.

Penggunaan teknologi digital dalam melakukan ibadah bukanlah hal yang menghilangkan esensi ibadah, karena sejatinya gereja merupakan persekutuan, dan persekutuan dibangun atas dasar iman kepada Yesus Kristus. Gereja rumah pada masa rasul-rasul dapat diimplikasikan dalam bentuk gereja digital pada masa kini ${ }^{33}$, masa digitalisasi. Kembali pada esensi ibadah yang ingin dibangun, yakni pertumbuhan iman dalam pengenalan pribadi kepada Yesus Kristus, sehingga menghasilkan buah iman, baik dalam bentuk kedewasaan dan jiwa yang dimenangkan. Jadi, implikasi berikut yang tidak dapat dilepaskan dari gereja rumah ini adalah melakukan misi Amanat Agung Yesus Kristus.

\section{Gereja Rumah Untuk Menuntaskan Amanat Agung}

Berkaca dari apa yang dilakukan Paulus atau jemaat mula-mula di dalam Kisah Para Rasul, maka rumah menjadi tempat mereka beribadah dan sekaligus bermisi. Fungsi dan manfaat yang dapat diwujudkan dari praktik gereja rumah adalah kegerakan-kegerakan misi. Dan hal itu dapat diterapkan dalam konteks masa kini, di mana orang Kristen "dipaksa" oleh keadaannya untuk beribadah di rumah. Gereja rumah menjadi satu tawaran dan sekaligus strategi yang dibangun oleh gereja itu sendiri untuk, pertama-tama, memperkuat sendi kehidupan iman keluarga Kristen, lalu, dapat menjangkau orang-orang yang dapat dihadirkan di "rumah" orang percaya.

Dalam konteks era digital saat ini, di mana gereja saat ini tercipta secara virtual ${ }^{34}$ melalui ibadah-ibadah digital, setidaknya telah menjadi sebuah perluasan Kerajaan Allah yang tidak lagi dibatasi oleh batas territorial dan geografis, karena teknologi internet telah menghadirkan

\footnotetext{
${ }^{31}$ Sonny Eli Zaluchu, "Eksegesis Kisah Para Rasul 2:42-47 Untuk Merumuskan Ciri Kehidupan Rohani Jemaat Mula-Mula Di Yerusalem," EPIGRAPHE: Jurnal Teologi dan Pelayanan Kristiani 2, no. 2 (2018): $72-$ 82, accessed April 1, 2020, http://www.stttorsina.ac.id/jurnal/index.php/epigraphe.

${ }^{32}$ Harls Evan Siahaan, "Karakteristik Pentakostalisme Menurut Kisah Para Rasul," DUNAMIS (Jurnal Teologi dan Pendidikan Kristiani) 2, no. 1 (2017): 12-28.

${ }^{33}$ Franz Foltz and Frederick Foltz, "Religion on the Internet: Community and Virtual Existence," Bulletin of Science, Technology and Society 23, no. 4 (2003): 321-330.

${ }^{34}$ Robert Glenn Howard, "Enacting a Virtual 'Ekklesia': Online Christian Fundamentalism as Vernacular Religion,” New Media and Society 12, no. 5 (2010): 729-744.
} 
kebeba-san untuk mengekspresikan bentuk pelayanan yang ingin dibangun dan disajikan bagi masyarakat digital saat ini. Dunia di era digitial sekarang ini telah menghadirkann masyarakat yang sangat familiar dengan gadget sehingga konsumsi sehari-hari adalah apa yang disajikan di dunia maya. Ibadah-ibadah live streaming di satu sisi telah menjadi semacam opsi bagi setiap orang untuk memilih akan beribadah seperti apa dan berkiiblat ke mana. Selain itu, ibadah-ibadah streaming dapat dinikmati oleh siapa pun yang mau dan tertarik untuk menikmatinya tanpa harus dirinya seorang Kristen.

Irwan Widjaja menjelaskan pertumbuhan gereja Indonesia secara keseluruhan mengalami pertumbuhan tetapi tidak signifikan, karena yang sedang terjadi saat ini adalah pertumbuhan dengan berbagai strategi ${ }^{35}$ : Pertumbuhan gereja melalui program penjangkauan; Pertumbuhan gereja melalui gereja sel; Pertumbuhan gereja melalui penanaman gereja yang di sengaja (Intentional Church Planting); Gerakan Penanaman Gereja (Church Multiplication through church planting movements); Pengembangan Kerajaan Allah melalui kegerakan pemuridan secara holistic (Kingdom Expansion through disciple making movements). Penerapan gereja rumah yang dimulai dari masa pandemi Covid-19 kiranya dapat terus dikembangkan demi meningkatkan pertumbuhan gereja yang sehat dan signifikan, terutama melalui kegiatan misi.

\section{Kesimpulan}

Peristiwa pandemi Covid-19 ini dapat menjadi momentum untuk bangkitnya gereja rumah; dengan adanya larangan pemerintah demi untuk memutus mata rantai penyebaran penularan Covid-19. Gereja harus dapat mengubah rintangan dan tantangan menjadi peluang untuk membangun gereja rumah dengan mempertimbangkan manfaat yang signifikan dari pelaksanaan gereja rumah tersebut. Gereja dapat saling belajar satu sama lain tentang praktik terbaik dan strategi yang efektif untuk tetap menjalankan fungsinya. Penelitian ini memiliki keterbatasan, baik dari segi artikel terkait untuk membangun teori dan pemahaman yang lebih luas, maupun evaluasi yang masih terbatas oleh karena isu yang masih terjadi ini membatasi ruang gerak penelitian. Namun demikian, penelitian selanjutnya dapat dibangun dengan mempertimbangkan manfaat gereja rumah dalam rangka mengentaskan kemiskinan Injil agar kegiatan misi Amanat Agung dapat terlaksana dengan maksimal dan terarah. Penelitian lain yang dapat dikembangkan adalah mereformat sebuah bentuk gereja rumah atau gereja komunitas yang berbasis teknologi digital.

\section{Ucapan Terima Kasih}

Penelitian ini merupakan penelitian kolaborasi yang menggabungkan beberapa ide dari beberapa dosen dari dua Sekolah Tinggi Teologi (STT). Terima kasih kepada Candra Gunawan dan Mangiring Tua Togatorop dari STT REAL, Batam yang telah memberikan masukan-masukan terkait praktik pastoral dan ibadah rumah di tengah pandemi ini, sehingga membuat penelitian ini lebih baik dan mendalam pada persoalan pastoral serta misi. Terima kasih juga kepada Handreas Hartono dari Sekolah Tinggi Teologi Pelita Bangsa, Jakarta, yang telah memberikan masukan mengenai misi amanat agung dan kaitannya dengan digitalisasi

\footnotetext{
${ }^{35}$ Fransiskus Irwan Widjaja, Misiologi Antara Teori, Fakta Dan Pengalaman, 1st ed. (Yogyakarta: Andi Offset, 2018), 94-95.
} 
gereja masa kini. Beberapa koreksi dari beliau telah memberikan arah pembahasan paper ini semakin fokus pada konsep gereja rumah di era digitalisasi sekarang ini.

\section{Referensi}

Branick, V. The House Church in the Writings of Paul. Wilmington, Delaware: Michael Glazier, 1989.

Brown, Collin, ed. New International Dictionary of New Testament Theology. Vol. 2. Grand Rapids: Zondervan Publishing House, 1986.

Corrie, John, ed. Dictionary of Mission Theology: Evangelical Foundations. Nottingham: IVP, 2007.

Deguma, Jabin J., Melona C. Deguma, Jemima N. Tandag, and Harlene Marie B. Acebes. "Where Is the Church in the Time of COVID-19 Pandemic: Preferring the Poor via G. Gutierrez' 'Liberation' and the Catholic Church's Social Teaching in the Philippine Setting." Journal of Social and Political Sciences 3, no. 2 (2020): 363-374. https://www.asianinstituteofresearch.org/JSParchives/Where-is-the-Church-in-the-Timeof-COVID-19-Pandemic\%3A-Preferring-the-Poor-via-G.-Gutierrez'-"Liberation"-andthe-Catholic-Church's-Social-Teaching-in-the-Philippine-Setting.

Dwiraharjo, Susanto. "Kajian Eksegetikal Amanat Agung Menurut Matius 28 : 18-20." Jurnal Teologi Gracia Deo 1, no. 2 (2019): 56-73. http://sttbaptisjkt.ac.id/ejournal/index.php/graciadeo.

E.A. Judge. "The Social Pattern of Christian Groups in the First Century." The Journal of Romans Studies 50, no. 1-2 (1960): 283.

Ellis EE. Pauline Theology: Ministry and Society. Grand Rapids: Eerdmans, 1989.

Evans, CM, Egan JR, and Hall I. "Pneumonic Plague in Johannesburg, South Africa, 1904." Emerging Infectious Diseases 24, no. 1 (2018): 95-102.

Foltz, Franz, and Frederick Foltz. "Religion on the Internet: Community and Virtual Existence." Bulletin of Science, Technology and Society 23, no. 4 (2003): 321-330.

Gehring, R. "House Church and Mission: The Importance of Household Structures in Early Christianity." The Journal of Theological Studies 58, no. 2 (2007): 666-671.

Hidajat, Djeffry. "Gereja Di Rumah: Kontekstualisasi Fungsi-Fungsi Rumah Dalam Masa Perjanjian Baru Untuk Pekabaran Injil." Veritas : Jurnal Teologi dan Pelayanan 17, no. 2 (December 2018): 107-117.

Howard, Robert Glenn. "Enacting a Virtual 'Ekklesia': Online Christian Fundamentalism as Vernacular Religion." New Media and Society 12, no. 5 (2010): 729-744.

Kittel, G, and G Friedrich. Theological Dictionary of the New Testament. Edited by W. Tr. Geoffrey and Bromiley. 5th ed. Grand Rapids: Eerdmans, 1985.

Nishiura, H. "Epidemiology of a Primary Pneumonic Plague in Kantoshu, Manchuria, from 1910 to 1911: Statistical Analysis of Individual Records Collected by the Japanese Empire." International Journal Epidemiol 35, no. 1 (2006): 1059-1065.

Panjaitan, F. Lumingkewas, M. S. "Ibadah Jemaat Kristen Kontemporer Abad 21 Dan Tinjauan Kritis-Liturgis.” FIDEI: Jurnal Teologi Sistematika dan Praktika 2, no. 1 (2019): 162-185.

Saputra, Eka Yudah. "WHO Tetapkan COVID-19 Sebagai Pandemi, Apa Maksudnya?" Tempo. Accessed March 20, 2020. https://dunia.tempo.co/read/1318511/who-tetapkancovid-19-sebagai-pandemi-apa-maksudnya/full\&view=ok.

Schnabel, E.J. Early Christian Mission: Paul and the Early Church. Downers Grove: IVP Books, 2004.

Siahaan, Harls Evan. "Karakteristik Pentakostalisme Menurut Kisah Para Rasul.” DUNAMIS (Jurnal Teologi dan Pendidikan Kristiani) 2, no. 1 (2017): 12-28. 
Siahaan, Harls Evan R. "Aktualisasi Pelayanan Karunia Di Era Digital.” EPIGRAPHE: Jurnal Teologi dan Pelayanan Kristiani 1, no. 1 (2017): 23-38. www.stttorsina.ac.id/jurnal/index.php/epigraphe.

Widjaja, Fransiskus Irwan. Misiologi Antara Teori, Fakta Dan Pengalaman. 1st ed. Yogyakarta: Andi Offset, 2018.

Yusuf, Thalia. Gaya Hidup Orang Percaya Berlandaskan Mazmur 91 : 1-16 Dalam Menyikapi Masalah Virus Corona (Covid-19) Masa Kini. Toraja, 2020. https://osf.io/kc6ea/.

Zaluchu, Sonny Eli. "Eksegesis Kisah Para Rasul 2:42-47 Untuk Merumuskan Ciri Kehidupan Rohani Jemaat Mula-Mula Di Yerusalem.” EPIGRAPHE: Jurnal Teologi dan Pelayanan Kristiani 2, no. 2 (2018): 72-82. Accessed April 1, 2020. http://www.stttorsina.ac.id/jurnal/index.php/epigraphe.

"Hindari Kontak, Kemenag Harap Gereja Gelar Ibadah Secara Online.” Accessed March 29, 2020. https://bimaskristen.kemenag.go.id/news-126-hindari-kontak-kemenag-harapgereja-gelar-ibadah-secara-online.html.

https://hub.jhu.edu/novel-coronavirus-information/, diakses tanggal20 maret 2020

http://covid-monitoring.kemkes.go.id/, diakses tanggal 21 Maret 2020

https://kbbi.web.id/sampar disadur tanggal 21 Maret 2020

BibleWorks7, CD-ROM

https://www.history.com/topics/middle-ages/black-death, 21 Maret 2020 